Prepared in cooperation with the San Antonio Water System

\title{
Groundwater Levels and Water-Quality Observations Pertaining to the Austin Group, Bexar County, Texas, 2009-11
}

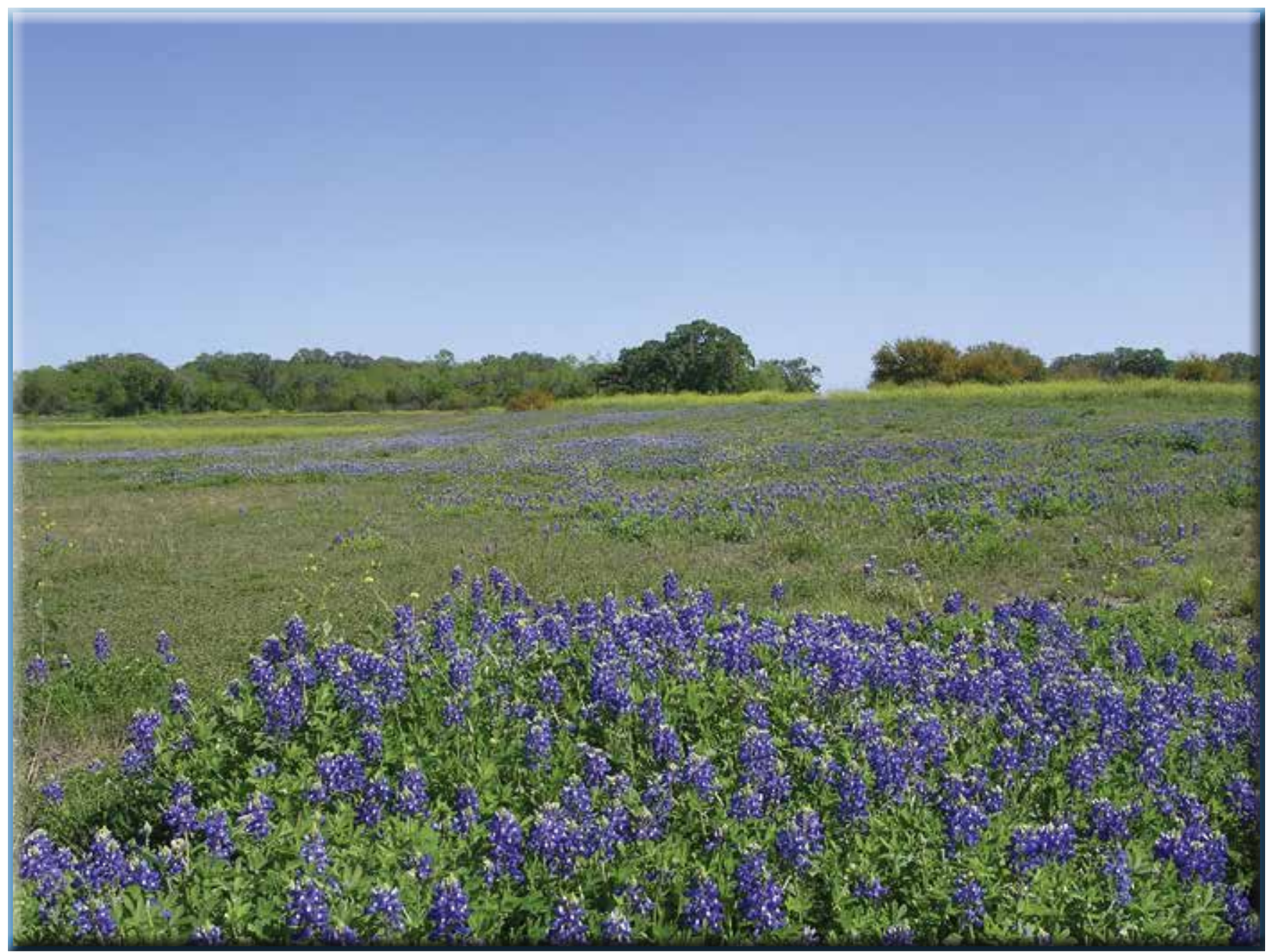

Scientific Investigations Report 2012-5278 
Front cover: McAllister Park near U.S. Geological Survey station 293305098265301, San Antonio, Texas, March 21, 2012.

Back cover: $\quad$ U.S. Geological Survey station 293305098265301, San Antonio, Texas, March 30, 2011. 


\section{Groundwater Levels and Water-Quality Observations Pertaining to the Austin Group, Bexar County, Texas, 2009-11}

By J. Ryan Banta and Allan K. Clark

Prepared in cooperation with the San Antonio Water System

Scientific Investigations Report 2012-5278 


\title{
U.S. Department of the Interior \\ KEN SALAZAR, Secretary \\ U.S. Geological Survey \\ Marcia K. McNutt, Director
}

\section{U.S. Geological Survey, Reston, Virginia: 2012}

\author{
This and other USGS information products are available at http://store.usgs.gov/ \\ U.S. Geological Survey \\ Box 25286, Denver Federal Center \\ Denver, CO 80225 \\ To learn about the USGS and its information products visit http://www.usgs.gov/ \\ 1-888-ASK-USGS
}

\footnotetext{
Any use of trade, product, or firm names is for descriptive purposes only and does not imply endorsement by the U.S. Government.

Although this report is in the public domain, permission must be secured from the individual copyright owners to reproduce any copyrighted materials contained within this report.
}

Suggested citation:

Banta, J.R., and Clark, A.K., 2012, Groundwater levels and water-quality observations pertaining to the Austin Group, Bexar County, Texas, 2009-11: U.S. Geological Survey Scientific Investigations Report 2012-5278, 18 p., 2 apps. 


\section{Contents}

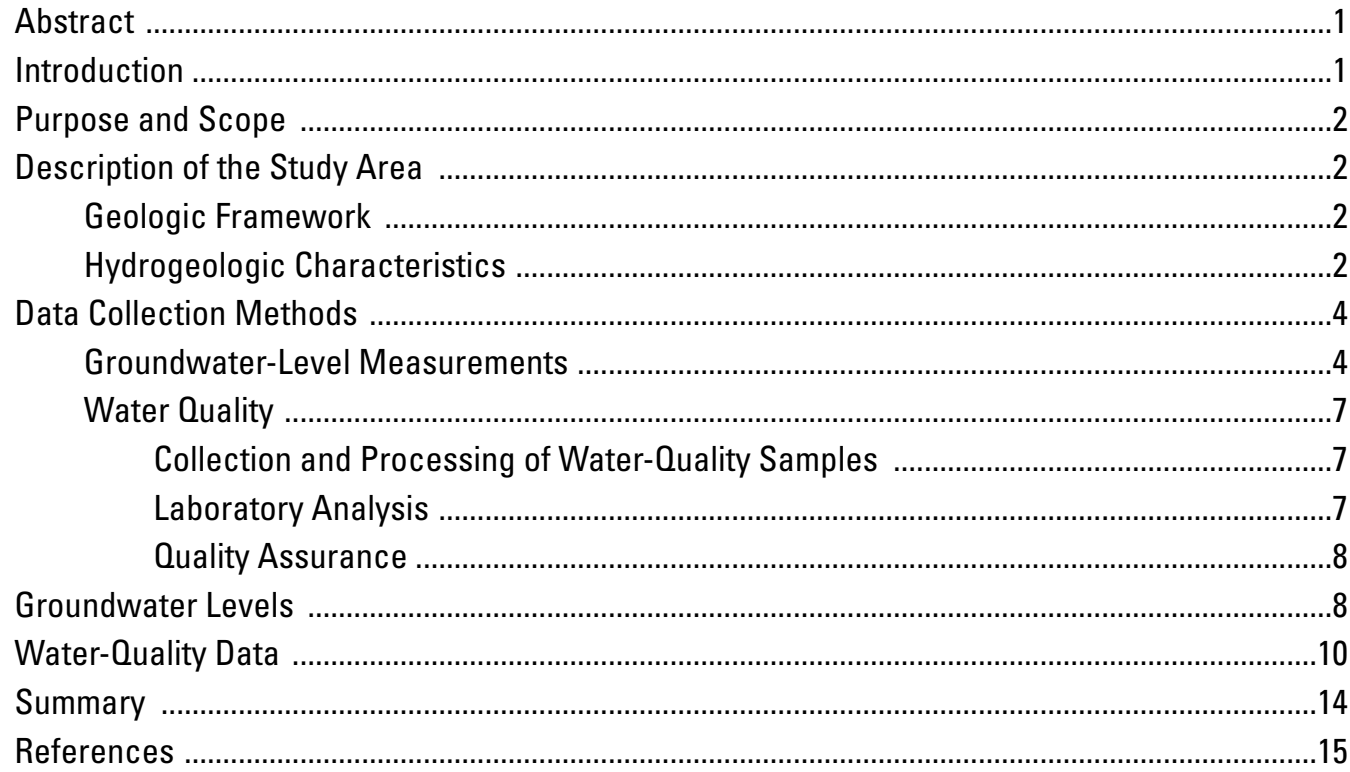

Appendixes (available at http://pubs.usgs.gov/sir/2012/5278/)

1. Daily mean groundwater-level altitudes, in feet above North American Vertical Datum of 1988, at sites in the study area, Bexar County, Texas, 2009-11

2. Water-quality samples and associated quality-control samples collected in the study area, Bexar County, Texas

\section{Figures}

1. Map showing location of data-collection sites in the study area, Bexar County, Texas, 2009-11

2. Map showing surficial geologic units, Edwards aquifer outcrop, and datacollection sites in the study area, Bexar County, Texas

3. Graphs showing $A$, Hydrographs of daily mean groundwater-level altitudes during 2009-11 of sites in the study area, Bexar County, Texas, and $B$, weekly precipitation measured at National Weather Service station number 417945 (San Antonio International Airport)

4. Trilinear diagrams of chemical composition for samples collected in the study area, Bexar County, Texas, April 2011

5. Graphs showing relations between molar ratios and strontium-87/strontium-86 isotopic ratios for samples collected in the study area, Bexar County, Texas, April 2010

6. Graph showing relation of hydrogen and oxygen isotopic ratios for samples collected in the study area, Bexar County, Texas, April 2010 


\section{Tables}

1. Data-collection sites in the study area, Bexar County, Texas, 2009-11

2. Summary of geologic framework and hydrogeologic characteristics of stratigraphic units in central Bexar County, Texas

\section{Conversion Factors}

\section{Inch/Pound to SI}

\begin{tabular}{|c|c|c|}
\hline Multiply & By & To obtain \\
\hline \multicolumn{3}{|c|}{ Length } \\
\hline inch (in.) & 25.4 & millimeter (mm) \\
\hline foot (ft) & 0.3048 & meter $(\mathrm{m})$ \\
\hline mile (mi) & 1.609 & kilometer $(\mathrm{km})$ \\
\hline \multicolumn{3}{|c|}{ Area } \\
\hline square mile $\left(\mathrm{mi}^{2}\right)$ & 2.590 & square kilometer $\left(\mathrm{km}^{2}\right)$ \\
\hline \multicolumn{3}{|c|}{ Volume } \\
\hline gallon (gal) & 3.785 & liter (L) \\
\hline
\end{tabular}

Temperature in degrees Celsius $\left({ }^{\circ} \mathrm{C}\right)$ may be converted to degrees Fahrenheit $\left({ }^{\circ} \mathrm{F}\right)$ as follows:

$$
{ }^{\circ} \mathrm{F}=\left(1.8 x^{\circ} \mathrm{C}\right)+32
$$

Temperature in degrees Fahrenheit $\left({ }^{\circ} \mathrm{F}\right)$ may be converted to degrees Celsius $\left({ }^{\circ} \mathrm{C}\right)$ as follows:

$$
{ }^{\circ} \mathrm{C}=\left({ }^{\circ} \mathrm{F}-32\right) / 1.8
$$

Vertical coordinate information is referenced to the North American Vertical Datum of 1988 (NAVD 88).

Horizontal coordinate information is referenced to the North American Datum of 1983 (NAD 83). Specific conductance is given in microsiemens per centimeter at 25 degrees Celsius $(\mu \mathrm{S} / \mathrm{cm}$ at $\left.25^{\circ} \mathrm{C}\right)$.

Concentrations of chemical constituents in water are given either in milligrams per liter (mg/L) or in micrograms per liter $(\mu \mathrm{g} / \mathrm{L})$. 


\title{
Groundwater Levels and Water-Quality Observations Pertaining to the Austin Group, Bexar County, Texas, 2009-11
}

\author{
By J. Ryan Banta and Allan K. Clark
}

\section{Abstract}

The U.S. Geological Survey, in cooperation with the San Antonio Water System, examined groundwaterlevel altitudes (groundwater levels) and water-quality data pertaining to the Austin Group in Bexar County, Texas, during 2009-11. Hydrologic data collected included daily mean groundwater levels collected at seven sites in the study area. Water-quality samples were collected at six sites in the study area and analyzed for major ions, nutrients, trace elements, organic carbon, and stable isotopes. The resulting datasets were examined for similarities between sites as well as similarities to data from the Edwards aquifer in Bexar County, Tex. Similarities in the groundwater levels between sites completed in the Austin Group and site J (State well AY-68-37-203; hereafter referred to as the "Bexar County index well") which is completed in the Edwards aquifer might be indicative of groundwater interactions between the two hydrologic units as a result of nearby faulting or conduit flow. The groundwater levels measured at the sites in the study area exhibited varying degrees of similarity to the Bexar County index well. Groundwater levels at site A (State well AY-68-36136) exhibited similar patterns as those at the Bexar County index well, but the hydrographs of groundwater levels were different in shape and magnitude in response to precipitation and groundwater pumping, and at times slightly offset in time. The groundwater level patterns measured at sites C, D, and E (State wells AY-68-29-513, AY-68-29-514, and AY-68-29512 , respectively) were not similar to those measured at the Bexar County index well. Groundwater levels at site F (State well AY-68-29-819) exhibited general similarities as those observed at the Bexar County index well; however, there were several periods of notable groundwater-level drawdowns at site $\mathrm{F}$ that were not evident at the Bexar County index well. These drawdowns were likely because of pumping from the well at site $\mathrm{F}$. The groundwater levels at sites $\mathrm{H}$ and I (State wells AY-68-37-205 and AY-68-29-932, respectively) exhibited similar patterns as those at the Bexar County index well (coefficient of determination $\left[\mathrm{R}^{2}\right]$ of 0.99 at both wells), indicating there might be some degree of hydrologic connectivity to the Edwards aquifer.
In general, the water-quality data indicated that the samples were representative of a calcium carbonate dominated system. The major ion chemistry and relations between magnesium to calcium molar ratios and ${ }^{87} \mathrm{Sr} r{ }^{86} \mathrm{Sr}$ isotopic ratios of samples collected from sites $\mathrm{H}$ and I indicated that the groundwater from these sites was most geochemically similar to groundwater collected from site B (State well AY-68-36-134), which is representative of groundwater in the Edwards aquifer. Of the sites sampled in this study, there appears to be varying hydrologic connectivity between groundwater from wells completed in the Austin Group and the Edwards aquifer.

\section{Introduction}

San Antonio, in Bexar County, Texas, was the seventh largest city in the United States in 2010, and its population increased 16 percent between 2000 and 2010 (U.S. Census Bureau, 2010). The Edwards aquifer is considered one of the most productive karst aquifers in the nation (Sharp and Banner, 1997), and it is the primary source of drinking water for San Antonio and the surrounding communities. Because of increases in population and water demands, water resource managers seek to gain a better understanding of the hydrogeologic characteristics of water-bearing units in the greater San Antonio area and of possible relations these units might have to the Edwards aquifer. One such hydrogeologic unit is the Austin Group, commonly referred to as the "Austin Chalk."

The Austin Group is considered a confining unit of the Edwards aquifer (Maclay and Small, 1984) and is geologically separate from the Edwards Group (which comprises the Edwards aquifer). There is historical and anecdotal evidence that the Austin Group might have some hydrogeologic connectivity to the Edwards aquifer through faults, fractures, or caves (Small, 1986; Clark, 2003). In some locations, wells completed in the Austin Group can produce water at rates of more than 500 gallons per minute, whereas at other locations, wells completed in the Austin Group produce only enough water for domestic and livestock needs (Arnow, 1963). Garza 
(1962, p. 9) reported that many of the wells completed in the Austin Group yielded only small quantities of water with hydrogen sulfide gas in "objectionable quantities," but also noted that in some areas, wells completed in the Austin Group may produce moderate quantities of water "similar in chemical quality" to groundwater in the Edwards aquifer. At the time of this study, there were few data available with which to characterize the hydrogeologic properties of the Austin Group in Bexar County, Tex. The U.S. Geological Survey (USGS), in cooperation with the San Antonio Water System, completed a reconnaissance-level study to measure groundwater-level altitudes and collect water-quality samples pertaining to the Austin Group in Bexar County, Tex., during 2009-11.

\section{Purpose and Scope}

This report documents a reconnaissance-level assessment during 2009-11 of daily mean groundwater-level altitudes and selected water-quality data pertaining to the Austin Group, in Bexar County, Tex. Water-quality data included measurements of physical properties, major ions, nutrients, trace elements, organic carbon, and stable isotopes. The groundwater level and water quality data were examined for similarities between sites as well as to data collected from the Edwards aquifer in Bexar County, Tex., to assess possible relations between the Austin Group and the Edwards aquifer.

\section{Description of the Study Area}

The study area covers approximately 377 square miles within the Balcones fault zone in central Bexar County, Tex. (fig. 1; table 1). The study area ranges from the approximate southern extent of the surficial expression of the Edwards Group (outcrop of the Edwards aquifer; fig. 2) in the north, to the borders of Bexar County in the west and east, and to U.S. Highway 90 and Interstate 10 in the south (fig. 1). The climate in the study area is subtropical subhumid (Larkin and Bomar, 1983). The average annual rainfall during 1971-2000 at the San Antonio International Airport (National Weather Service station 417945) was approximately 32.9 inches per year (in/ yr) (National Oceanic and Atmospheric Administration, 2012). Rainfall was approximately $30.7,37.4$, and $17.6 \mathrm{in} / \mathrm{yr}$ during 2009, 2010, and 2011, respectively (National Oceanic and Atmospheric Administration, 2012).

\section{Geologic Framework}

The Austin Group is an Upper Cretaceous Age marine sediment consisting primarily of chalk and interbedded marls (Koger, 1981; Small, 1986; Hanson and Small, 1994; Maclay, 1995), which unconformably overlies the Eagle Ford Group (Martinez, 1982), and is one of a series of geologic formations that make up the confining units of the Edwards aquifer in central Bexar County, Tex. (figs. 1, 2; table 2). The confining units of the Edwards aquifer include the Georgetown Formation, Del Rio Clay, Buda Limestone, Eagle Ford Group, Austin Group, Taylor Group (Anacacho Limestone and Pecan Gap Chalk), and Navarro Group (table 2).

The Austin Group is subject to structural controls associated with the Balcones fault zone (Hill and Vaughn, 1898; Arnow, 1963; Maclay and Land, 1988). The Balcones fault zone is an en echelon, normal fault system (George, 1952), with fault blocks typically downthrown to the southeast toward the coast. The Balcones fault zone trends southwest to northeast, but a smaller set of secondary or cross-faults trend southeast to northwest (Clark, 2005). Many of the faults in the Balcones fault zone are not single, sharp breaks as shown on geologic maps but are actually shatter zones (Arnow, 1959). Secondary fractures, which resulted from the faulting, are generally at strikes between 45 and 145 degrees from the primary fault (Clark, 2005). Additionally, some of the faults might not result in topographic relief, partly because the rocks on both sides of the fault have similar weathering characteristics, and possibly because the rate of movement was approximately the same as the rate of erosion (Stein and Ozuna, 1995). Dissolution associated with preferential groundwater flow paths might enhance the permeability of fault and fracture systems, including solution enlargement at scales from individual fractures to cave networks (Ferrill, 2004). Where these openings reach the surface or intersect other pathways such as faults or sinkholes that extend to the surface, they provide paths for surface water infiltration, or exchange of water between formations (Maclay, 1995). An example of solution-enlarged fractures in the Austin Group within the study area is Robber Baron Cave (fig. 1), which has over 4,000 feet (ft) of mapped cave networks (Veni, 1988). In another example, Ewing (1996) reported numerous fractures and joints were observed at the Alamo Cement Quarry (fig. 1). The fractures and joints, spaced 0.5 to 8 -ft apart and up to $40-\mathrm{ft}$ long, were determined to be the result of geologic factors and not of blasting during quarry processes (Ewing, 1996).

\section{Hydrogeologic Characteristics}

Water entering the Austin Group in Bexar County, Tex., is likely derived from multiple sources, including direct infiltration of precipitation and infiltration along stream channels where the Austin Group outcrops. Because the Austin Group is generally categorized as a confining unit of the Edwards aquifer and not as a separate water-bearing aquifer, the term "Austin Group" will hereinafter be used to describe both the geologic framework and hydrologic characteristics of the formation. The Edwards aquifer, which is comprised of the Edwards Group and underlies the Austin Group in Bexar County, Tex., is similarly recharged from surface water infiltrating where the Edwards Group outcrops, including outcrops west of the study area (Ashworth and Hopkins, 1995). 


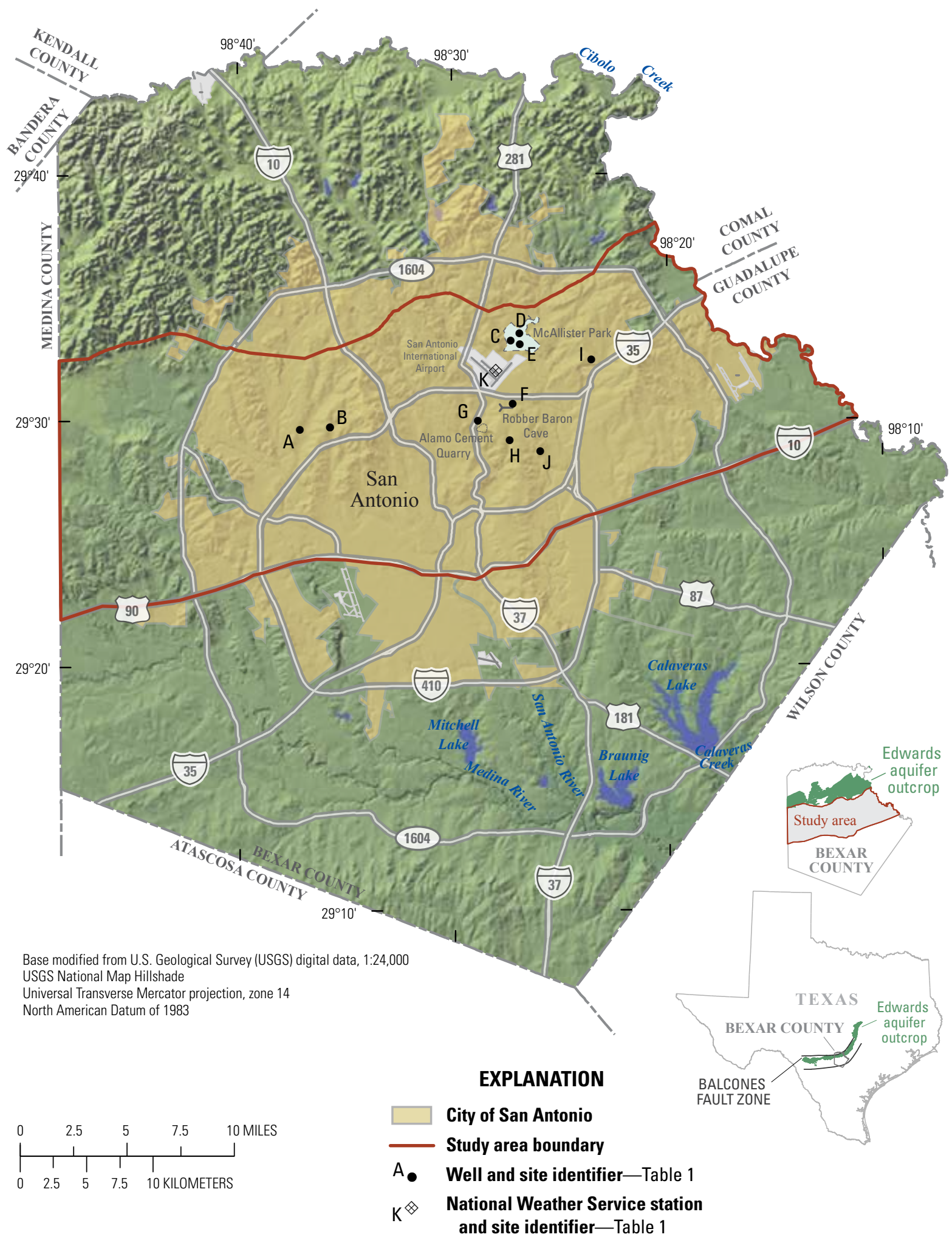

Figure 1. Location of data-collection sites in the study area, Bexar County, Texas, 2009-11 (modified from Pedraza and Shah, 2010). 
Table 1. Data-collection sites in the study area, Bexar County, Texas, 2009-11.

[dd, degrees; mm, minutes; ss, seconds; WL, groundwater-level altitude; QW, water-quality sample; --, not applicable]

\begin{tabular}{ccccccccc}
\hline $\begin{array}{c}\text { Site } \\
\text { identifier } \\
\text { (fig. 1) }\end{array}$ & $\begin{array}{c}\text { U.S. Geological } \\
\text { Survey } \\
\text { station number }\end{array}$ & $\begin{array}{c}\text { State well } \\
\text { number }\end{array}$ & $\begin{array}{c}\text { Latitude } \\
\text { (dd mm ss) }\end{array}$ & $\begin{array}{c}\text { Longitude } \\
\text { (dd mm ss) }\end{array}$ & $\begin{array}{c}\text { Elevation' } \\
\text { (feet) }\end{array}$ & $\begin{array}{c}\text { Geologic } \\
\text { unit of well } \\
\text { completion }\end{array}$ & $\begin{array}{c}\text { Type of } \\
\text { data }\end{array}$ & $\begin{array}{c}\text { Period of } \\
\text { water-level record } \\
\text { used in report }\end{array}$ \\
\hline A & 292938098370901 & AY-68-36-136 & $29^{\circ} 29^{\prime} 38^{\prime \prime}$ & $98^{\circ} 37^{\prime} 09^{\prime \prime}$ & 816 & Austin Group & WL & Aug. 2009-Dec. 2011 \\
B & 292943098354403 & AY-68-36-134 & $29^{\circ} 29^{\prime} 43^{\prime \prime}$ & $98^{\circ} 35^{\prime} 44^{\prime \prime}$ & 848 & Edwards Group QW & -- \\
C & 293314098271801 & AY-68-29-513 & $29^{\circ} 33^{\prime} 14^{\prime \prime}$ & $98^{\circ} 27^{\prime} 18^{\prime \prime}$ & 747 & Austin Group & WL & July 2009-Dec. 2011 \\
D & 293332098265301 & AY-68-29-514 & $29^{\circ} 33^{\prime} 32^{\prime \prime}$ & $98^{\circ} 26^{\prime} 53^{\prime \prime}$ & 746 & Austin Group & WL & July 2009-Dec. 2011 \\
E & 293305098265301 & AY-68-29-512 & $29^{\circ} 33^{\prime} 05^{\prime \prime}$ & $98^{\circ} 26^{\prime} 53^{\prime \prime}$ & 766 & Austin Group & WL, QW & July 2009-Dec. 2011 \\
F & 293040098271301 & AY-68-29-819 & $29^{\circ} 30^{\prime} 40^{\prime \prime}$ & $98^{\circ} 27^{\prime} 13^{\prime \prime}$ & 799 & Austin Group & WL, QW & July 2009-Dec. 2011 \\
G & 292959098285002 & AY-68-37-133 & $29^{\circ} 29^{\prime} 59^{\prime \prime}$ & $98^{\circ} 28^{\prime} 50^{\prime \prime}$ & 712 & Austin Group & QW & -- \\
H & 292910098272201 & AY-68-37-205 & $29^{\circ} 29^{\prime} 10^{\prime \prime}$ & $98^{\circ} 27^{\prime} 22^{\prime \prime}$ & 804 & Austin Group & WL, QW & Aug. 2009-Dec. 2011 \\
I & 293228098233301 & AY-68-29-932 & $29^{\circ} 32^{\prime} 28^{\prime \prime}$ & $98^{\circ} 23^{\prime} 33^{\prime \prime}$ & 763 & Austin Group & WL, QW & Aug. 2009-Dec. 2011 \\
J & -- & AY-68-37-203 & $29^{\circ} 28^{\prime} 44^{\prime \prime}$ & $98^{\circ} 25^{\prime} 57^{\prime \prime}$ & 731 & Edwards Group WL & July 2009-Dec. 2011 \\
\hline
\end{tabular}

\begin{tabular}{|c|c|c|c|c|c|c|c|}
\hline $\begin{array}{c}\text { Site } \\
\text { identifier }\end{array}$ & $\begin{array}{l}\text { National Weather } \\
\text { Service station } \\
\text { number }\end{array}$ & $\begin{array}{l}\text { National Weather } \\
\text { Service station name }\end{array}$ & $\begin{array}{l}\text { Latitude } \\
\text { (dd mm ss) }\end{array}$ & $\begin{array}{l}\text { Longitude } \\
\text { (dd mm ss) }\end{array}$ & $\begin{array}{c}\text { Elevation } \\
\text { (feet) }\end{array}$ & $\begin{array}{l}\text { Type of } \\
\text { data }\end{array}$ & $\begin{array}{l}\text { Period of record } \\
\text { used in report }\end{array}$ \\
\hline
\end{tabular}

\section{Data Collection Methods}

Though many wells in the study area penetrate the Austin Group, the majority of wells were completed in a deeper formation, such as the Edwards Group; hence, the wells used in this study represent wells completed in the Austin Group (that is, did not penetrate deeper formations) that were available for sampling. Daily mean groundwaterlevel altitudes were reported by the USGS in seven wells completed in the Austin Group (State wells AY-68-36-136 [site A], AY-68-29-513 [site C], AY-68-29-514 [site D], AY-6829-512 [site E], AY-68-29-819 [site F], AY-68-37-205 [site H], and AY-68-29-932 [site I]) (fig. 1; table 1; appendix 1). Groundwater levels reported by the Edwards Aquifer Authority (2012) for the Bexar County index well (State well AY-68-37-203 [site J]) were used for comparison purposes (fig. 1; table 1; appendix 1). The Bexar County index well is also commonly referred to as the "J-17 index well" (Edwards Aquifer Authority, 2012). Water-quality samples collected from six sites in the study area (State well AY-68-36-134 [site B], State well AY-68-37-133 [site G], and sites E, F, H, and I) (fig. 1, table 1; appendix 2) were analyzed for major ions, nutrients, trace elements, and stable isotopes. Note that sites E, F, G, H, and I were completed in the Austin Group, whereas site B is completed in the Edwards aquifer. All measured constituents are presented in appendix 2 for completeness. Precipitation data were compiled from the National Weather Service cooperative station number 417945 San Antonio International Airport during 2009-11 (fig. 1; table 1).

\section{Groundwater-Level Measurements}

Groundwater-level measurements, reported as depth to water (in feet) below the land surface, were made every 15 minutes with a pressure transducer and transferred to the USGS National Water Information System (NWIS) database (U.S. Geological Survey, 2012). The groundwater-level data were verified and corrected as necessary by periodic measurements by using a graduated electric tape (Freeman and others, 2004; Cunningham and Schalk, 2011). Daily mean groundwater-level altitudes (hereinafter referred to as "groundwater levels") were calculated by subtracting the daily mean depth to water below the land surface from the land-surface datum (the elevation of the land surface above North American Datum 1988 [NAVD88]). Sites F, H, and I had a previously installed pump, whereas sites A, C, D, and E did not. Groundwater pumping at sites F, H, and I were for domestic or commercial purposes. Periods of pumping were not known, so corrections for pumping were not made to the groundwater-level records. 


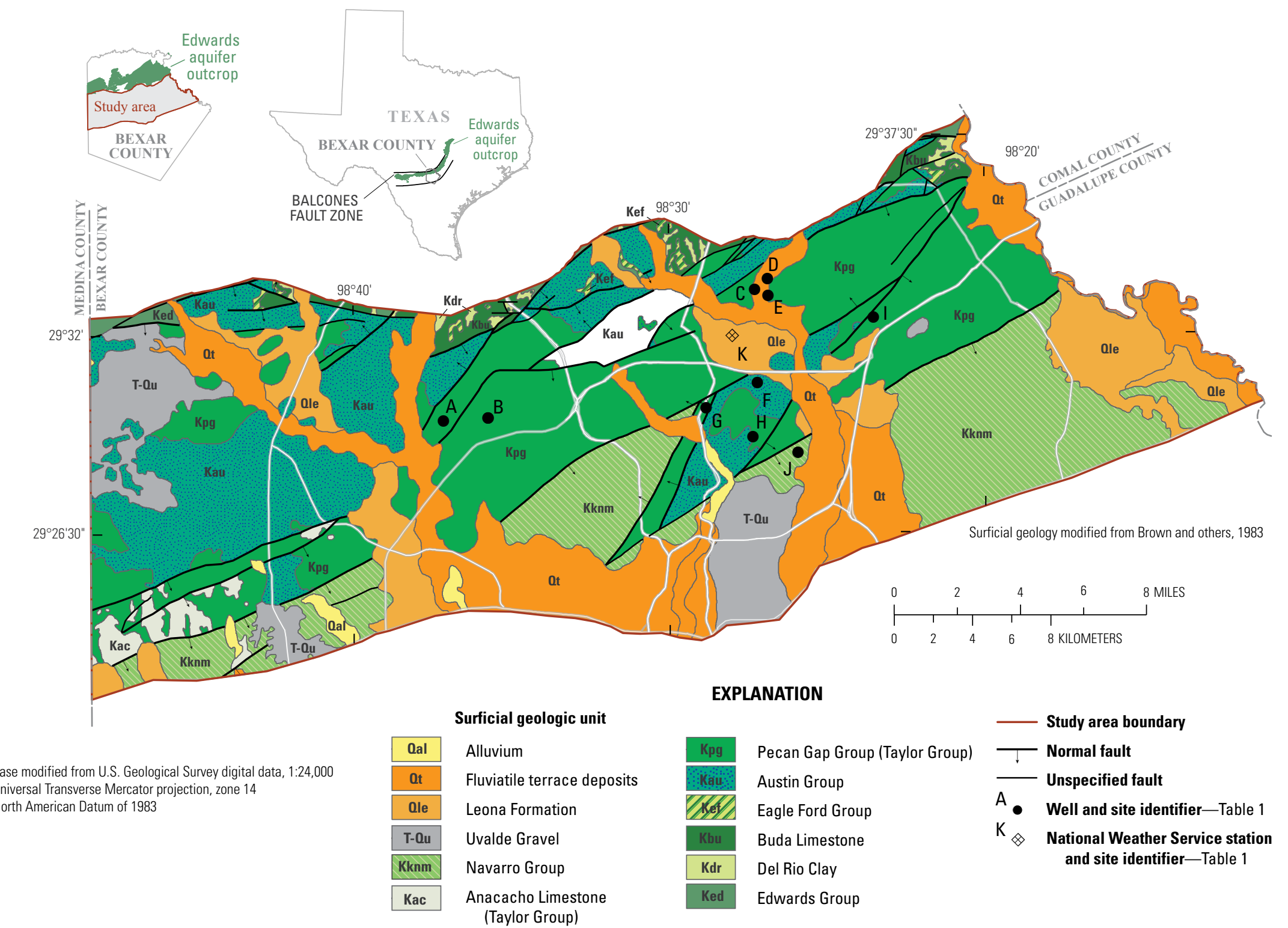

Figure 2. Surficial geologic units, Edwards aquifer outcrop, and data-collection sites in the study area, Bexar County, Texas (modified from Pedraza and Shah, 2010). 
Table 2. Summary of geologic framework and hydrogeologic characteristics of stratigraphic units in central Bexar County, Texas.

[System modified from Maclay and Small (1984); Group or formation modified from Sellards and others (1923) and Brown and others (1983); thickness modified from Livingston (1947), Stein and Ozuna (1995), and Blome and others (2005); lithology modified from Dunham (1962); hydrologic function and water-yielding characteristics modified from Maclay and Small (1984), and Livingston (1947); --, not available; AQ, aquifer; na, not applicable; CU, confining unit; table modified from Pedraza and Shah (2010)]

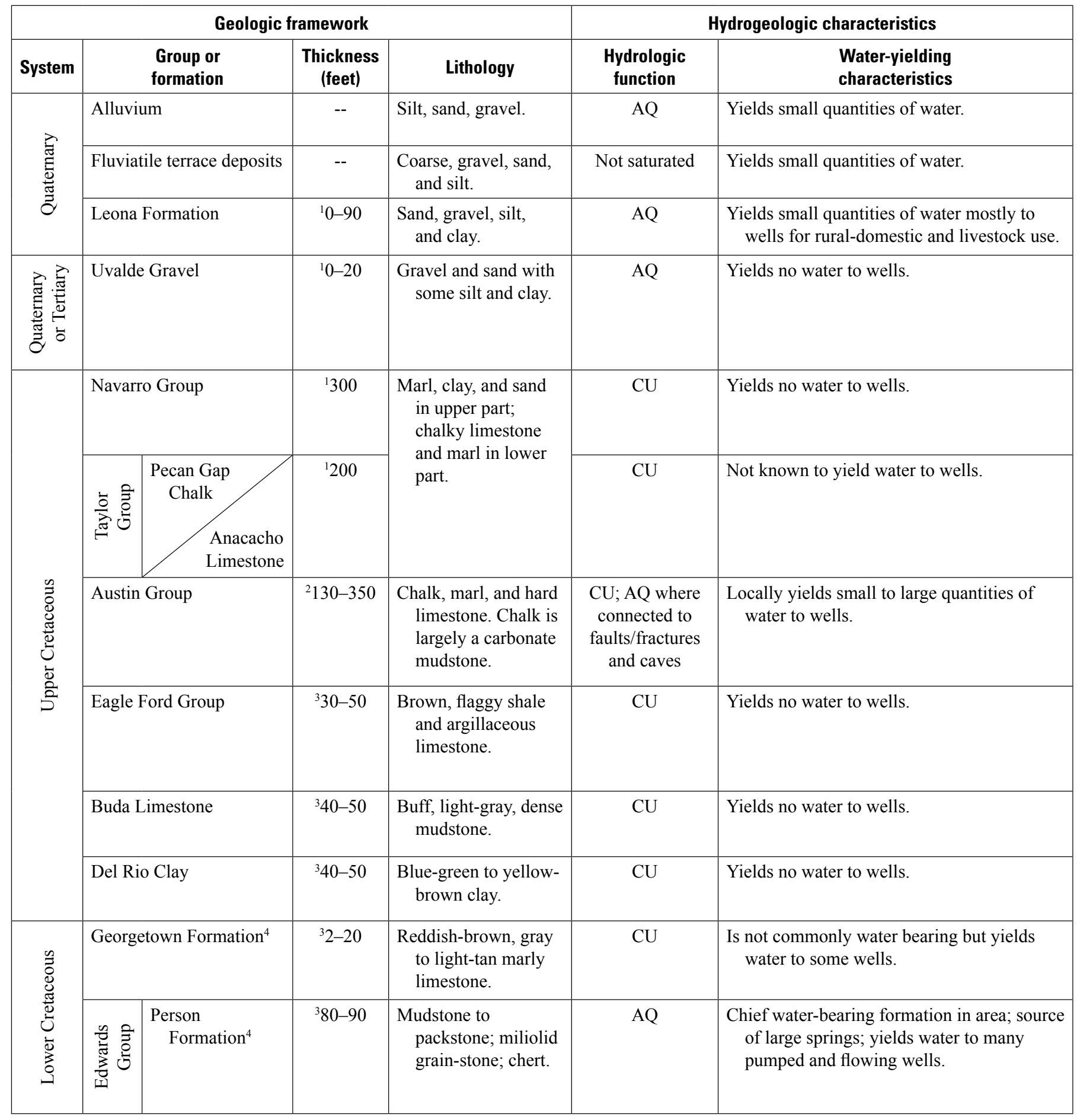

\footnotetext{
${ }^{1}$ Livingston, 1947.
}

${ }^{2}$ Blome and others, 2005.

${ }^{3}$ Stein and Ozuna, 1995.

${ }^{4}$ Not shown in study area. 


\section{Water Quality}

\section{Collection and Processing of Water-Quality Samples}

Sample collection and processing techniques followed standard USGS protocols (U.S. Geological Survey, variously dated). Water-quality samples were collected from raw-water spigots at or near the wellhead, prior to any pressure tanks or water treatment, for wells that had previously installed pumps (sites F, G, H, and I; fig. 1). If the well did not have a previously installed pump (sites B and E; fig. 1), the sample was collected by lowering a submersible piston pump equipped with 3/8-inch Teflon-lined tubing into the well (U.S. Geological Survey, variously dated). Before samples were collected and processed, all wells except for site F were purged to remove at least three casing volumes of water or until physical properties measured in the field (dissolved oxygen, $\mathrm{pH}$, specific conductance, water temperature, and turbidity) stabilized (U.S. Geological Survey, 2006). Purging the well was done to ensure that the samples collected were representative of water from the aquifer. Physical properties were measured onsite by inserting a multiparameter probe into a sample removed from the well at the time of sample collection. Physical property measurements were considered stable when five consecutive measurements, which were made every 5 minutes, were within the stabilization criteria for the water-quality indicators (Wilde, variously dated). Only one casing volume of water was removed from site $\mathrm{F}$ prior to sampling because the well stopped producing water at the rate at which water was being pumped. After the one casing volume of water was removed from site $\mathrm{F}$, the pump was turned off, and groundwater refilled the well. The sample was collected when enough water was present in the well to fill the sample bottles (U.S. Geological Survey, 2006). Samples were transported to the USGS south-central Texas program office and were then processed (U.S. Geological Survey, variously dated). Samples were filtered through a 0.45 -micron filter, acidified to $\mathrm{pH}$ less than 2, and then shipped at 4 degrees Celsius $\left({ }^{\circ} \mathrm{C}\right)$ to the National Water Quality Laboratory (NWQL) in Denver, Colorado, for laboratory analysis.

\section{Laboratory Analysis}

Water-quality samples were analyzed for major ions, nutrients, trace elements, and organic carbon concentrations by the NWQL (appendix 2). Major inorganic ions were analyzed by using methods described by Fishman and Friedman (1989) and Fishman (1993). Nutrients were analyzed by using methods documented by Fishman (1993) and Patton and Kryskalla (2011). Trace elements were analyzed by using methods described by Fishman and Friedman (1989), Garbarino (1999), and Garbarino and others (2006). Total organic carbon was analyzed by using methods described by Clesceri and others (1998). Dissolved organic carbon was analyzed by using methods described by Brenton and Arnett (1993).

Concentrations for major ion, nutrients, and trace elements were reported by the laboratory as described by Oden and others (2011, p. 9):

The analytical quantification procedure used by the NWQL for reporting results is based on the long-term method detection level (LT-MDL) and laboratory reporting level (LRL). The LT-MDL concentrations are defined as a censoring limit for most analytical methods at the NWQL, and its purpose is to limit the false positive rate to less than or equal to 1 percent. An LT-MDL is a modification of the [U.S. Environmental Protection Agency] 40 Code of Federal Regulations Part 136 definition of the method detection limit (MDL). The LRL is defined as twice the LT-MDL and is established to limit the occurrence of false negative detections to less than or equal to 1 percent (Childress and others, 1999). A constituent concentration is considered estimated by the laboratory when results are greater than the LT-MDL and less than the LRL; that is, a detection is considered likely, but quantification is considered questionable. The remark code of "E" (estimated) is assigned by the laboratory for these results.

When the measured values were greater than the calibration range of the instrument or when the field measurement stabilization criteria were not met, the data were reported with an "E" remark code (Childress and others, 1999; Wilde, variously dated).

Stable isotopic ratios of carbon $\left(\delta^{13} \mathrm{C}\right)$ were measured by the National Ocean Sciences Accelerator Mass Spectrometry Facility at the Woods Hole Oceanographic Institution in Woods Hole, Massachusetts, by using methods described by Vogel and others (1987), Donahue and others (1990), McNichol and others (1992), Gagnon and Jones (1993), McNichol and others (1994), and Schneider and others (1994). The results were reported by the laboratory in units of parts per thousand (per mil). Isotopic ratios of hydrogen $(\delta \mathrm{D})$ and oxygen $\left(\delta^{18} \mathrm{O}\right)$ were measured by the USGS Stable Isotope Laboratory in Reston, Virginia (RSIL), by using methods described by Révész and Coplen (2008a, 2008b). The results were reported by the laboratory in per mil relative to Vienna Standard Mean Ocean Water (VSMOW). The isotopic ratios of strontium (strontium-87/strontium-86 $\left[{ }^{87} \mathrm{Sr} /{ }^{86} \mathrm{Sr}\right]$ ) were measured by the USGS National Research Program Laboratory in Menlo Park, California, by using methods described by Bullen and others (1996) and reported as a dimensionless ratio. The laboratory reported ${ }^{87} \mathrm{Sr} r{ }^{86} \mathrm{Sr}$ ratio for standard reference material (SRM) 987 from the National Institute of Standards and Technology as $0.71024(0.00002$ 2-sigma, 95 percent confidence level). 


\section{Quality Assurance}

Quality-control samples (an equipment blank and a replicate sample) were collected to evaluate potential contamination of the water-quality samples and data variability. In order to evaluate potential contamination as a result of the sampling equipment and sample processing, the equipment blank sample was collected prior to the start of sampling from a well where a preexisting pump was not installed. The equipment blank was identified with State well number AY-68-36-135 (appendix 2), though an environmental sample was not collected from this site. The equipment blank sample was intended to measure potential contamination from the sampling equipment, including the submersible pump sampling equipment which was not used when the sample was collected from the spigot at the wellhead. To be conservative, the concentrations measured in all of the environmental samples (including those not collected with a submersible pump) were compared to the concentrations measured in the equipment blank sample. The equipment blank was analyzed for major ions, nutrients, and trace elements. Calcium, chloride, copper, manganese, molybdenum, and nickel were detected in the equipment blank sample. All other analyzed constituent concentrations were less than the LRL. The concentrations of calcium, chloride, and molybdenum were less than concentrations measured in the environmental samples, indicating possible contamination likely did not affect the concentrations in the environmental samples. For samples in which measured concentrations of copper and manganese in the equipment blank sample were greater than those measured in the environmental samples, the environmental sample data were rejected because contamination might have affected the environmental results; rejected are not reported herein.

The replicate sample was collected from site I to evaluate the potential variability introduced during sample collection, processing, or laboratory analysis (appendix 2). The replicate sample was compared to the associated environmental sample by calculating the relative percent difference (RPD) for each pair of detected constituents (eq. 1; appendix 2). The RPD was computed with the equation

$$
\mathrm{RPD}=\left[\left|\mathrm{X}_{1}-\mathrm{X}_{2}\right|\right] /\left[\left(\mathrm{X}_{1}+\mathrm{X}_{2}\right) / 2\right] \times 100,
$$

where

$$
\begin{gathered}
\mathrm{X}_{1} \quad \begin{array}{l}
\text { is the concentration of the constituent } \\
\text { measured in the environmental sample; and }
\end{array} \\
\mathrm{X}_{2} \quad \begin{array}{l}
\text { is the concentration of the constituent } \\
\text { measured in the sequential-replicate } \\
\text { sample. }
\end{array}
\end{gathered}
$$

The RPD was not computed for a constituent pair if either of the values was reported as less than the LRL. RPDs of 10 percent or less were used to indicate good agreement between analytical results if the concentrations were sufficiently large compared to the LRL. RPDs of 10 percent or less were measured for most constituents, indicating that there was acceptable agreement and reproducibility between the environmental sample values and the sequential replicate value. The calculated RPDs that exceeded 10 percent were iron (34 percent), lead (22 percent), nickel (17 percent), and antimony (58 percent). The RPDs for iron and antimony might have been above 10 percent because the reported values were relatively small (less than four times the LRL).

\section{Groundwater Levels}

In karst groundwater systems, changes in groundwater levels are often associated with changes in hydrologic conditions such as precipitation or drought conditions. The changes in groundwater levels measured at the Bexar County index well (site J), which is completed in the Edwards aquifer, were assumed to be a general indicator of changes in groundwater levels for the Edwards aquifer on a regional scale in Bexar County, and have been linked with regional climate and pumping events (Lindgren and others, 2004). Similarities between the groundwater levels of wells completed in the Austin Group in the study area and the Bexar County index well might be indicative of groundwater interactions between the Edwards aquifer and Austin Group through structural or hydrologic processes such as nearby faulting or conduit flow, though the degree of connectivity (if any) is unknown.

The groundwater levels reported at the sites in the study area exhibited varying degrees of similarity to groundwater levels reported for the Bexar County index well (fig. 3). The coefficient of determination $\left(\mathrm{R}^{2}\right)$ can be used to indicate the relation between two variables of interest (Helsel and Hirsh, 2002; Navidi, 2008). Groundwater levels at site A exhibited similar patterns as those at the Bexar County index well $\left(\mathrm{R}^{2}\right.$ of 0.91), but the hydrographs of groundwater levels were different in shape and magnitude in response to precipitation and groundwater pumping, and at times slightly offset in time. The similar behavior in groundwater levels at site $\mathrm{A}$ indicated that some degree of hydrologic connectivity between this site and the Edwards aquifer is possible, although a high coefficient of determination value does not necessarily indicate causality (Navidi, 2008). Additionally, groundwater levels at site A were higher in altitude by approximately 50-70 $\mathrm{ft}$ than the groundwater levels at the Bexar County index well. This difference might exist because groundwater levels in Edwards aquifer are generally higher in the northwest part of the study area than groundwater levels at the Bexar County index well (Lindgren and others, 2004). Site A might also be influenced by local processes, such as flows in nearby creeks acting as sources of local recharge. For example, the difference in groundwater levels at site A compared to those at the Bexar County index well increased from approximately $50 \mathrm{ft}$ during fall 2009 to up to approximately $70 \mathrm{ft}$ during summer 2010 (following an extended wet period), but returned to approximately $50 \mathrm{ft}$ about the beginning of 2011 

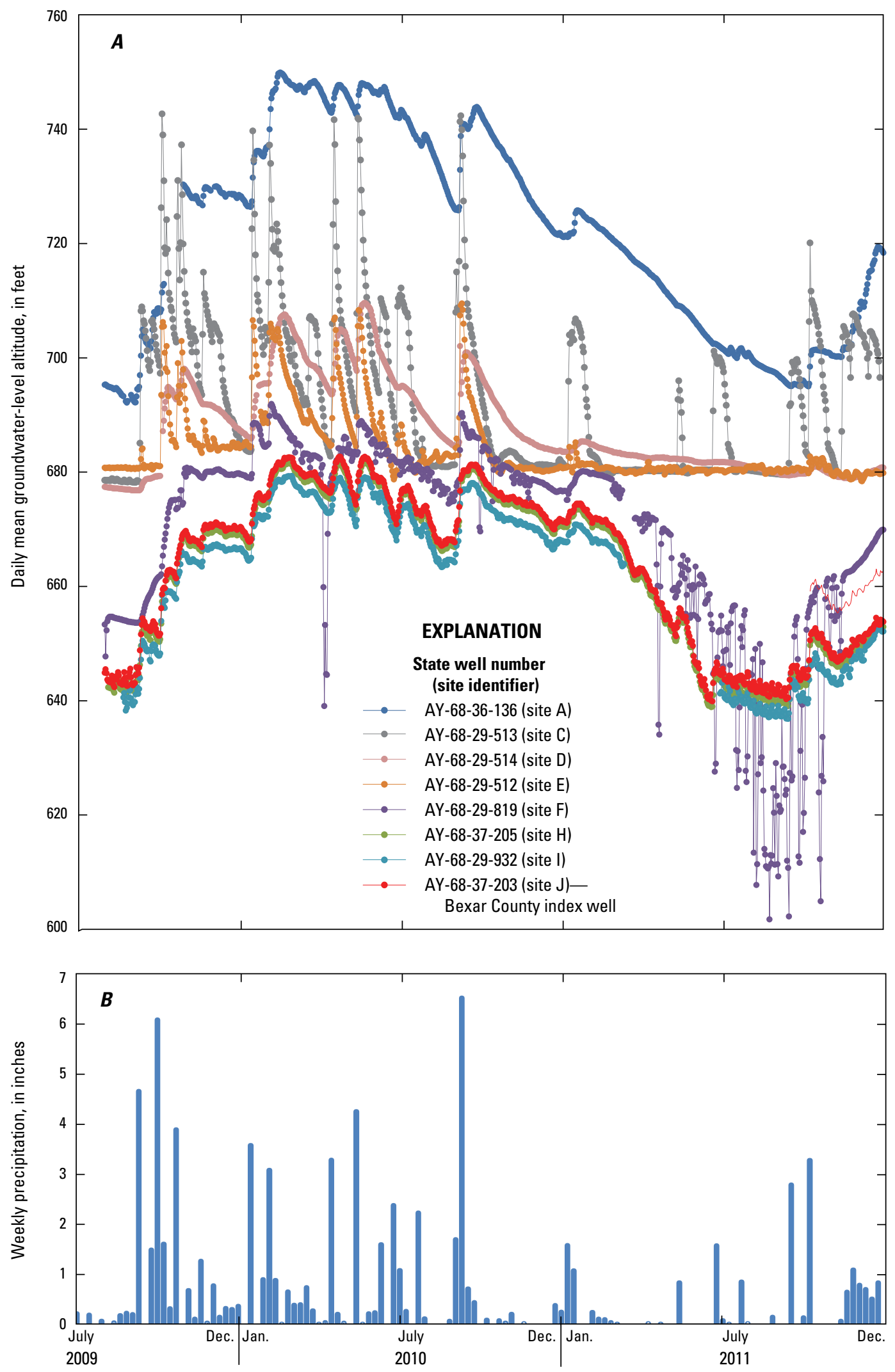

Figure 3. A, Hydrographs of daily mean groundwater-level altitudes during 2009-11 of sites in the study area, Bexar County, Texas, and $B$, weekly precipitation measured at National Weather Service station number 417945 (San Antonio International Airport). 
(the beginning of an extended dry period) (fig. 3). Also, a downhole video camera deployed at site A showed a clear conduit of water flowing into the well at approximately 90 ft below land surface (Chris Villarreal, U.S. Environmental Protection Agency, written commun., 2010); hence, the groundwater levels observed at site A might be related in part to potential hydrologic connectivity to the Edwards aquifer, such as by faulting, in conjunction with influences from local hydrologic processes.

The pattern of groundwater levels from the sites in McAllister Park (sites C, D, and E) were the least similar to the pattern of groundwater levels measured at the Bexar County index well. The smaller coefficients of determination between groundwater levels at the Bexar County index well and site $\mathrm{C}\left(\mathrm{R}^{2}\right.$ of 0.13$)$, $\mathrm{D}\left(\mathrm{R}^{2}\right.$ of 0.66$)$, and $\mathrm{E}\left(\mathrm{R}^{2}\right.$ of 0.30$)$ indicated less connectivity to the Edwards aquifer as compared with sites $\mathrm{H}$ and $\mathrm{I}$ (both $\mathrm{R}^{2}$ of 0.99 ). The groundwater levels measured from the sites in McAllister Park appeared to have a relatively stable baseline at about $680 \mathrm{ft}$ above NAVD88; however, changes in groundwater levels at these sites occurred rapidly in response to precipitation events (fig. 3 ). The baseline at about $680 \mathrm{ft}$ above NAVD88 is present during wetter periods when groundwater levels at the Bexar County index well are relatively high (for example, during the spring 2010), as well as during drier periods (for example, during summer 2011). Groundwater levels at site $\mathrm{C}$ responded most appreciably, with sharp rises and falls in response to precipitation events. Groundwater levels at sites D and E also responded to precipitation events, but the rising and falling limbs of the hydrograph were more gradual than observed at site C.

The groundwater levels from site F were generally similar to those observed at the Bexar County index well; however, there were several periods of notable groundwaterlevel drawdowns at site $\mathrm{F}$ that were not observed at the Bexar County index well. These drawdowns were likely because of pumping from the well at site F, notably during the summer of 2011 when San Antonio experienced a prolonged dry period (Texas Commission on Environmental Quality, 2012). The hydrographs of groundwater levels measured at sites $\mathrm{H}$ and I were the most similar in shape and magnitude to those at the Bexar County index well indicating there might be some degree of hydrologic connectivity to the Edwards aquifer. The $\mathrm{R}^{2}$ between groundwater levels at the Bexar County index well and sites $\mathrm{H}$ and I were 0.99 .

\section{Water-Quality Data}

Water-quality samples were collected from six sites in the study area (sites B, and E-I). Water-quality samples were collected during a period of relatively stable hydrologic conditions (April, 2011) in order to minimize local effects such as precipitation recharge on the groundwater chemistry. For example, only 0.02 inches of precipitation occurred during the month prior to sampling (National Oceanic and
Atmospheric Administration, 2012). The water-quality data were examined to characterize the Austin Group and were compared to water-quality data of the Edwards aquifer. Trilinear (Piper) diagrams indicated that the groundwater samples had similar major ion chemical characteristics and generally can be categorized as a calcium-carbonate water type (fig. 4) (Piper, 1944).

A groundwater sample was collected at site B, which is completed in the Edwards aquifer. The major ion chemistry in the groundwater sample collected at site B plots similarly to the major ion chemistry of previously collected groundwater samples by the USGS at this site (Musgrove and others, 2011) indicating that the chemistry of the groundwater at site B was similar during the two sampling events. Musgrove and others (2011) found that water-quality samples collected from site B were representative of groundwater in the Edwards aquifer; hence, for the remainder of this report, site B is assumed to be representative of Edwards aquifer groundwater chemistry.

Samples collected from sites E, F, and G plot slightly separately from the sample collected from site B on the trilinear diagram (fig. 4). This indicates that there may be either site-specific unique conditions occurring at these sites, mixing with different source water, or a combination of both. For example, site $\mathrm{G}$ is located near a former cement quarry which was in operation from 1908 to 1985 (Rybczyk, 1992; Texas State Historical Association, 2012), and that is where the previously mentioned fractures were observed.

The major ion chemistry of samples collected from sites $\mathrm{H}$ and I are geochemically most similar to groundwater collected from site B, representative of groundwater in the Edwards aquifer. Because the Austin Group and Edwards aquifer are calcium carbonate dominated systems, some similarities in the geochemistry in the collected samples are to be expected. Although similarities in concentration values in samples collected from sites completed in the Austin Group and Edwards aquifer are present, it is not known if the water sampled from the sites completed in the Austin Group and Edwards aquifer are from the same source. Given the small sample dataset, it is not possible to differentiate the potential sources of groundwater collected from the Austin Group on the basis of major ion geochemistry.

Concentrations of the nutrients nitrate, nitrite, and orthophosphate measured in the collected groundwater samples varied between samples (appendix 2). For example, nitrate plus nitrite concentrations range from 0.02 milligrams per liter $(\mathrm{mg} / \mathrm{L})$ at site $\mathrm{G}$ to $2.54 \mathrm{mg} / \mathrm{L}$ at site $\mathrm{H}$. The concentration of nitrate plus nitrite at site B was $1.97 \mathrm{mg} / \mathrm{L}$, which is consistent with previously measured concentrations from Edwards aquifer groundwater samples (Musgrove and others, 2011). The nitrate plus nitrite concentration at site I (1.81 mg/L) was most similar to the concentration measured at site $\mathrm{B}(1.97 \mathrm{mg} / \mathrm{L})$ though concentrations at site $\mathrm{E}$ were also similar $(2.15 \mathrm{mg} / \mathrm{L})$. Further, the concentration of orthophosphate measured at site B $(0.014 \mathrm{mg} / \mathrm{L})$ was similar to concentrations measured at sites $\mathrm{H}$ and I $(0.014 \mathrm{mg} / \mathrm{L}$ for both samples). Orthophosphate concentrations in samples collected 


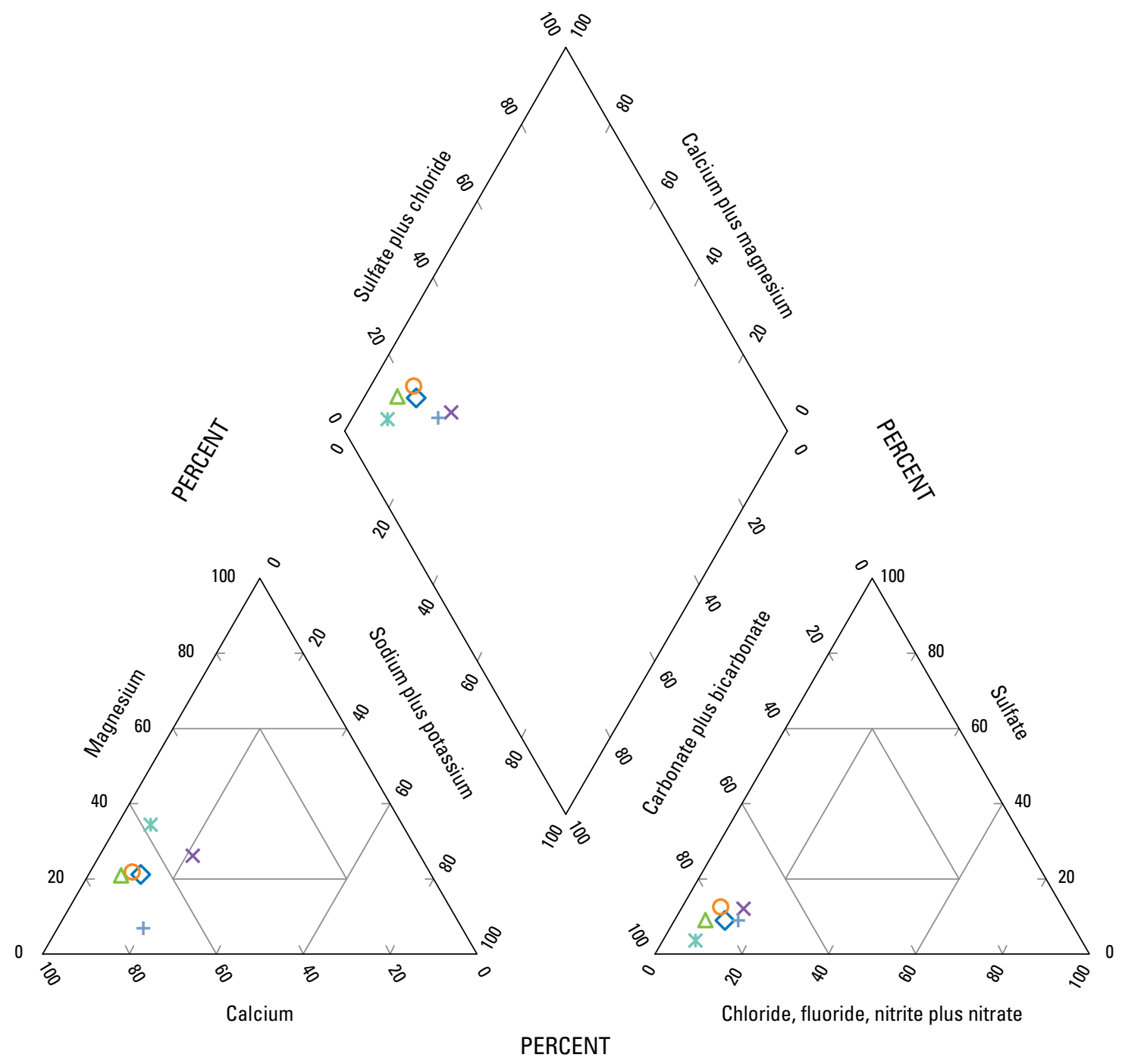

EXPLANATION

Sample collected from well, by State well number (site identifier)

$\triangle \quad$ AY-68-36-134 (site B)

$+\quad$ AY-68-29-512 (site E)

* AY-68-29-819 (site F)

$\times \quad$ AY-68-37-133 (site G)

$\diamond \quad$ AY-68-37-205 (site H)

O AY-68-29-932 (site I)

Figure 4. Trilinear diagrams of chemical composition for samples collected in the study area, Bexar County, Texas, April 2011. 
from sites $F$ and $G$ were slightly less $(0.010$ and $0.012 \mathrm{mg} / \mathrm{L}$, respectively), and the concentrations in samples from site $\mathrm{E}$ was slightly more $(0.024 \mathrm{mg} / \mathrm{L})$. Hence, a consistent pattern between sites was not observed in nutrient concentrations; however, nutrient concentrations measured in samples from sites $\mathrm{B}, \mathrm{H}$, and I were often the most similar, indicating a degree of hydrogeologic similarity between these sites.

Similar to nutrient concentrations, the trace element concentrations in the groundwater samples exhibited variability between samples, though a consistent pattern was not observed (appendix 2). Concentrations of barium, for example, ranged from 34.8 (site B) to 117 (site E) micrograms per liter $(\mu \mathrm{g} / \mathrm{L})$. Barium concentrations in samples collected from sites $\mathrm{H}$ and I were 60.5 and 41.4 $\mu \mathrm{g} / \mathrm{L}$, respectively. Concentrations of uranium ranged from 0.134 (site G) to 3.57 (site E) $\mu \mathrm{g} / \mathrm{L}$ with samples from sites $\mathrm{B}, \mathrm{H}$ and $\mathrm{I}$ having similar concentrations [ranging from 0.812 (site I) to 0.884 (site $\mathrm{H}$ ) $\mu \mathrm{g} / \mathrm{L}$ ]. The measured concentrations of organic carbon (filtered and unfiltered) were generally similar between samples collected at each of the sites. The measured concentrations of turbidity, many trace elements, and organic carbon (filtered and unfiltered) in the sample from site $\mathrm{F}$, however, were notably elevated compared to the concentrations measured at the other sites (appendix 2). These elevated concentrations may be in part because site $\mathrm{F}$ is an open hole well, has a comparatively low production rate (for example, the well stopped producing water at the rate at which water was being pumped during sampling), and only intermittently is used for domestic purposes. It is possible that this well is reflecting more local processes (for example, local lithology) than being representative of groundwater from the Austin Group; hence, it is included in the subsequent discussions and figures, but with so few data, the groundwater at site F might not be representative of local groundwater.

Groundwater can also be characterized through the use of relations between ratios of major ions, trace elements, or isotopes, which can be used as an indicator of water-rock interaction, geochemical evolution, or other geochemical processes (Clark and Fritz, 1997; Sharp and Banner, 1997; Fairchild and others, 2000; Banner, 2004; Mahler 2008; Musgrove and others, 2010; Banta and others, 2012). For example, increased magnesium to calcium $(\mathrm{Mg} / \mathrm{Ca})$ molar ratio and strontium to calcium $(\mathrm{Sr} / \mathrm{Ca})$ molar ratio, and decreased strontium isotopic ratios might be related to waterrock interactions and geochemical evolution (Fairchild and others, 2000; Musgrove and Banner, 2004; Musgrove and others, 2010).

The relations between $\mathrm{Mg} / \mathrm{Ca}$ molar ratios and ${ }^{87} \mathrm{Sr} /{ }^{86} \mathrm{Sr}$ isotopic ratios for samples collected in the study area are depicted in figure 5. The concentrations measured in the sample collected from site B are consistent with previous studies that characterized Edwards aquifer geochemistry (Musgrove and others, 2010). On the basis of chemical ratios, groundwater from site $\mathrm{E}$ appears to be the least geochemically evolved water of the samples collected in this study, possibly related in part that site $\mathrm{E}$ was the most responsive to local precipitation events and the least correlated with the Edwards aquifer of the sites sampled in this study. Site E had the highest measured specific conductivity of the samples collected, however, indicating the groundwater at site E may have had a longer residence time than the groundwater at some of the other sites. Hence, the groundwater geochemistry reflects that site $\mathrm{E}$ was possibly being recharged, at least in part, by local recharge events, which could potentially mean that the groundwater at this site might not be regionally recharged to the same extent as the Edwards aquifer.

The plot location of sites $\mathrm{F}$ and $\mathrm{G}$ on figure 5 indicate that the sampled groundwater might be more geochemically evolved than the other sites. As previously noted, site $\mathrm{F}$ is from an open hole and went dry during sample collection. Given the low productivity of the well, it is possible that the sampled groundwater had longer residence times. It might also indicate that local lithology is influencing the geochemistry through water-rock interaction. Another possibility is that the groundwater from sites $F$ and $G$ is mixing with another source of groundwater that has a different geochemical composition. The groundwater samples collected from sites $\mathrm{H}$ and $\mathrm{I}$ have similar $\mathrm{Mg} / \mathrm{Ca}$ and $\mathrm{Sr} / \mathrm{Ca}$ molar and ${ }^{87} \mathrm{Sr} /{ }^{86} \mathrm{Sr}$ isotopic ratios as groundwater in the Edwards aquifer (site B) (fig. 5).

The hydrogen and oxygen isotopic ratios can be used to evaluate geochemical interactions and possible source waters (Clark and Fritz, 1997; Kehew, 2001). The groundwater samples collected in this study ranged from -23.90 to -22.75 per mil for hydrogen $(\delta \mathrm{D})$, and -4.18 to -4.01 per mil for oxygen $\left(\delta^{18} \mathrm{O}\right)$. Comparing the hydrogen and oxygen isotopic sample data to the global meteoric water line (Craig, 1961) and the local meteoric water line (Pape and others, 2010) indicated the groundwater is meteoric in origin (fig. 6). Groundwater collected from the Austin Group does not appear to have a geochemically unique isotopic enrichment compared to groundwater collected from the Edwards aquifer (Musgrove and others, 2011).

The different relations among the groundwater-level data and the water-quality data indicate that the water quality in the different watersheds is likely influenced by differences in source areas, geochemical evolution, groundwater flow paths and residence time, local lithology, or some combination thereof. Determining the source areas and other possible contributors based on these data is not possible given the small sample size of the water-quality dataset (both in number of samples and spatial distribution of samples).

Though a single line of evidence might indicate some degree of hydrologic connectivity between the Austin Group and the Edwards aquifer (or a lack thereof), using multiple lines of evidence together can provide a better characterization of groundwater in the Austin Group and its potential hydrologic connectivity to the Edwards aquifer. Specifically, groundwater-level hydrology as compared to the Bexar County index well and geochemistry as compared 

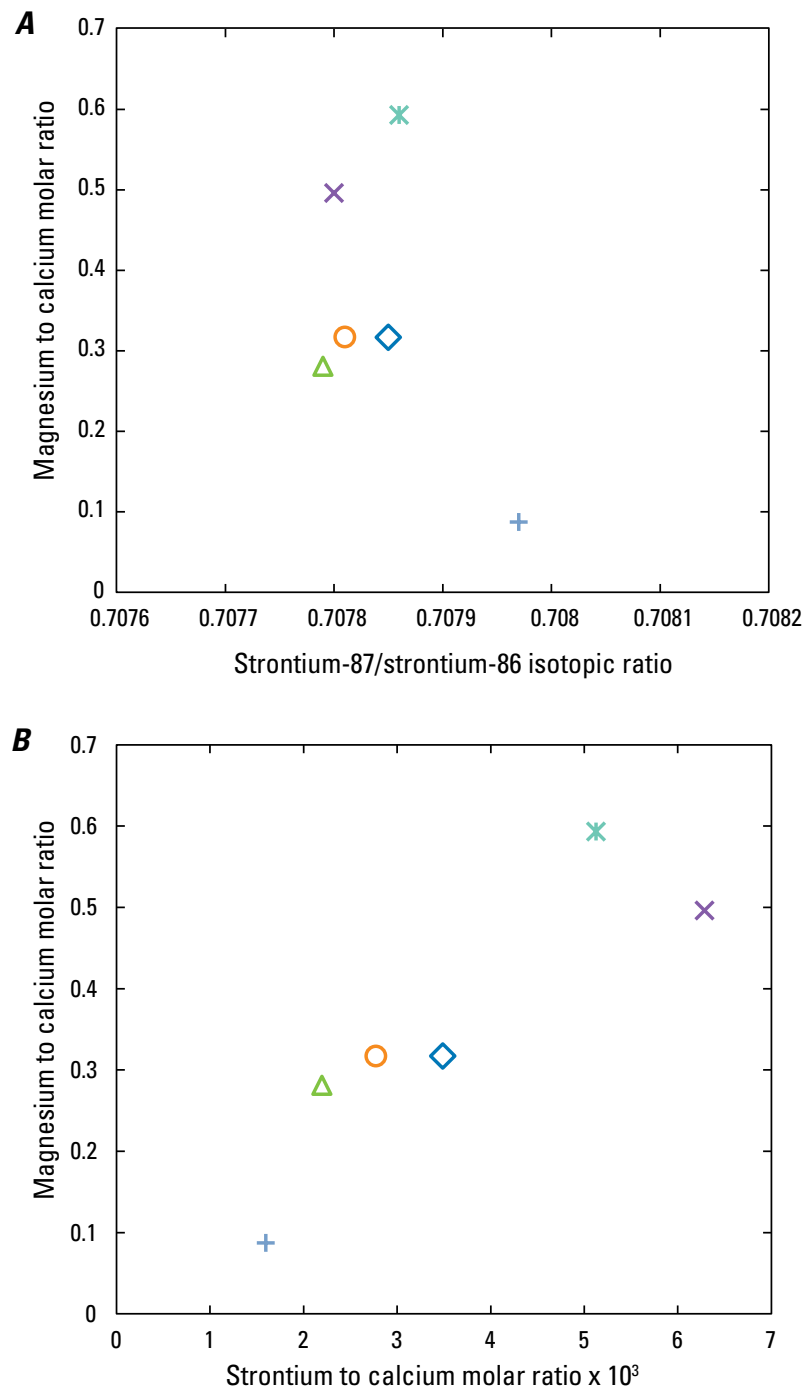

\section{EXPLANATION}

Sample collected from well, by State well number (site identifier)

$\triangle \quad$ AY-68-36-134 (site B)

$+\quad$ AY-68-29-512 (site E)

* AY-68-29-819 (site F)

$\times \quad A Y-68-37-133$ (site G)

$\diamond \quad A Y-68-37-205$ (site H)

O AY-68-29-932 (site I)

Figure 5. Relations between molar ratios and strontium-87/strontium-86 isotopic ratios for samples collected in the study area, Bexar County, Texas, April 2010. $A$, magnesium to calcium (Mg/Ca) molar ratio and strontium-87/strontium-86 isotopic ratio. $B$, magnesium to calcium $(\mathrm{Mg} / \mathrm{Ca})$ molar ratio and strontium to calcium $(\mathrm{Sr} / \mathrm{Ca})$ molar ratio.

with site $\mathrm{B}$ indicate that groundwater at well $\mathrm{E}$ is not as hydrologically similar to the Edwards aquifer groundwater as other sites sampled in the this study. Groundwater-level data from well $\mathrm{F}$ were similar to those from the Bexar County index well; however, the relation was not as clear as with some of the other wells in the study. Further, the trace element concentrations and isotopic ratios were not always consistent with those from site B. Lastly, of the sites sampled in this study, groundwater-level data, trilinear diagram, trace element concentrations, and isotopic ratios all indicate that sites $\mathrm{H}$ and I are the most hydrologically similar to site B. Of the sites sampled in this study, there appears to be varying hydrologic connectivity between groundwater from wells completed in the Austin Group wells and the Edwards aquifer. 


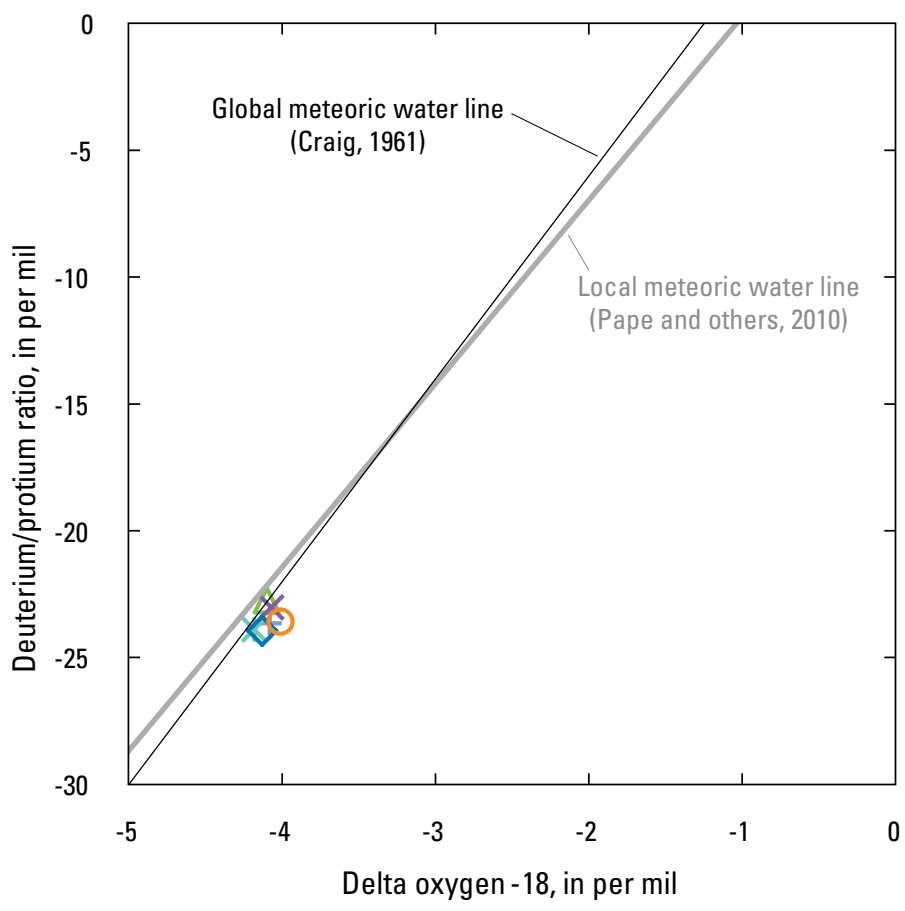

EXPLANATION

Sample collected from well, by State well number (site identifier)

$\triangle$ AY-68-36-134 (site B)

$+\quad$ AY-68-29-512 (site E)

* AY-68-29-819 (site F)

X AY-68-37-133 (site G)

$\diamond \quad A Y-68-37-205$ (site $\mathrm{H}$ )

AY-68-29-932 (site I)

Figure 6. Relation of hydrogen and oxygen isotopic ratios for samples collected in the study area, Bexar County, Texas, April 2010.

\section{Summary}

The Edwards aquifer is the primary source of drinking water for the City of San Antonio, in Bexar County, Texas, and surrounding areas and is considered to be one of the most productive karst aquifers in the nation. Because of increases in population and water demands, water resource managers seek to gain a better understanding of the hydrogeologic characteristics of water-bearing units in the greater San Antonio area and of possible relations these units might have to the Edwards aquifer. One such hydrogeologic unit is the Austin Group, commonly referred to as the "Austin Chalk." The U.S. Geological Survey (USGS), in cooperation with the San Antonio Water System, examined groundwaterlevel altitudes (groundwater levels) and water-quality data pertaining to the Austin Group in Bexar County, Texas during 2009-11.

This report documents a reconnaissance-level assessment during 2009-11 of daily mean groundwater level altitudes (groundwater levels) and selected water-quality data pertaining to the Austin Group, in Bexar County, Tex. Water-quality data included measurements of physical properties, major ions, nutrients, trace elements, organic carbon, and stable isotopes. The data were examined for similarities between sites, as well as to data from site J (State well AY-68-37-203; hereafter referred to as the "Bexar County index well"), which is completed in the Edwards aquifer.

Similarities between the groundwater levels of wells completed in the Austin Group in the study area and the Bexar County Index well might be indicative of groundwater interactions between the Edwards aquifer and the Austin Group through structural or hydrologic processes such as nearby faulting or conduit flow. The groundwater levels at the sites in the study area exhibited varying degrees of similarity to those recorded at the Bexar County index well. Groundwater levels at site A (State well AY-68-36-136) exhibited similar patterns as those at the Bexar County index well (coefficient of determination $\left[\mathrm{R}^{2}\right]$ of 0.91 ), but the hydrographs of groundwater levels were different in shape and magnitude in response to precipitation and groundwater pumping, and at times slightly offset in time. The groundwater levels at site A appear to be offset (higher) from the groundwater level at the Bexar County index well by approximately 50-70 feet. Groundwater levels at site A might be influenced by local hydrologic processes, such as flows in nearby creeks acting as a source of recharge.

The groundwater levels recorded at sites $\mathrm{C}, \mathrm{D}$, and $\mathrm{E}$ (State wells AY-68-29-513, AY-68-29-514, and AY-68-29-512, respectively) were not similar to those measured at the Bexar County index well. The lower relations between groundwater 
levels at the Bexar County index well and site $\mathrm{C}\left(\mathrm{R}^{2}\right.$ of $0.13), \mathrm{D}\left(\mathrm{R}^{2}\right.$ of 0.66$)$, and $E\left(\mathrm{R}^{2}\right.$ of 0.30$)$ indicated limited connectivity to the Edwards aquifer.

The groundwater levels from site $\mathrm{F}$ were generally similar to those observed at the Bexar County index well; however, there were several periods of notable groundwaterlevel drawdowns at site $\mathrm{F}$ that were not observed at the Bexar County index well. The groundwater levels at sites $\mathrm{H}$ and I (State wells AY-68-37-205 and AY-68-29-932, respectively) exhibited similar patterns compared to groundwater levels at the Bexar County index well ( $\mathrm{R}^{2}$ of 0.99 at both wells) indicating there might be some degree of hydrologic connectivity to the Edwards aquifer.

Water-quality samples were collected from six sites in the study area. The water quality data were examined to characterize the Austin Group and for relations to the Edwards aquifer. In general, the water-quality data indicated the samples were representative of a calcium carbonate dominated system. Of the samples collected in this study, the major ion chemistry of samples collected from sites $\mathrm{H}$ and I were most similar to groundwater collected from site $\mathrm{B}$, representative of groundwater in the Edwards aquifer. A consistent pattern in nutrient and trace element concentrations was not observed among the sample collected from site B as compared to those from the other sites that exhibited similar hydrograph characteristics and major ion chemistry; however, nutrient and trace element concentrations measured in samples from sites B, H, and I were often the most similar. Of the samples collected in this study, site E demonstrated the lowest geochemically evolved water. The relations between $\mathrm{Mg} / \mathrm{Ca}$ molar ratios and ${ }^{87} \mathrm{Sr} /{ }^{86} \mathrm{Sr}$ isotopic ratios for samples collected from sites $\mathrm{H}$ and I are similar to those measured at site $\mathrm{B}$, indicating that the groundwater from these sites were most geochemically similar to groundwater in the Edwards aquifer.

Though a single line of evidence might indicate some degree of hydrologic connectivity between the Austin Group and the Edwards aquifer (or a lack thereof), using multiple lines of evidence together can provide a better characterization of the Austin Group and its potential hydrologic connectivity. Specifically, groundwater-level hydrology as compared to the Bexar County index well and geochemistry as compared with site B indicate that groundwater at well $\mathrm{E}$ is not as hydrologically similar to the Edwards aquifer groundwater as other sites sampled in this study. Groundwater-level data from well $\mathrm{F}$ were more similar to those from the Bexar County index well; however, the relation was not as clear as with some of the other wells in the study. Further, the trace element concentrations and isotopic ratios were not always consistent with those from site B. Lastly, of the sites sampled in this study, groundwater-level data, trilinear diagram, trace element concentrations, and isotopic ratios all indicated that sites $\mathrm{H}$ and I were the most hydrologically similar to site B. Of the sites sampled in this study, there appears to be varying hydrologic connectivity between groundwater from wells completed in the Austin Group wells and the Edwards aquifer.

\section{References}

Arnow, Ted, 1959, Ground-water geology of Bexar County, Texas: Texas Board of Water Engineers, Bulletin 5911, 52 p.

Arnow, Ted, 1963, Ground-water geology of Bexar County, Texas: U.S. Geological Survey Water-Supply Paper 1588, $36 \mathrm{p}$.

Ashworth, J.B., and Hopkins, Janie, 1995, Major and minor aquifers of Texas: Texas Water Development Board Report $345,69 \mathrm{p}$.

Banner, J.L., 2004, Radiogenic isotopes-Systematics and applications to earth surface processes and chemical stratigraphy: Earth Science Reviews, v. 65, p. 141-194.

Banta, J.R., Lambert, R.B., Slattery, R.N., and Ockerman, D.J., 2012, Streamflow gain and loss and water quality in the upper Nueces River Basin, south-central Texas, 200810: U.S. Geological Survey Scientific Investigations Report 2012-5181, $40 \mathrm{p}$.

Blome, C.D., Faith, J.R., Pedraza, D.E., Ozuna, G.B., Cole, J.C., Clark, A.K., Small, T.A., and Morris, R.R., comps., 2005, Geologic map of the Edwards aquifer recharge zone, south-central Texas: U.S. Geological Survey Scientific Investigations Map 2873, version 1.1, 1 pl., scale 1:200,000, accessed October 22, 2012, at http://pubs.usgs.gov/ $\operatorname{sim} / 2005 / 2873 /$.

Brenton, R.W., and Arnett, T.L., 1993, Methods of analysis by the U.S. Geological Survey National Water Quality Laboratory-Determination of dissolved organic carbon by UV-promoted persulfate oxidation and infrared spectrometry: U.S. Geological Survey Open-File Report 92-480, $12 \mathrm{p}$.

Brown, T.E., Waechter, N.B., and Barnes, V.E., 1983, Geologic atlas of Texas, GA0029 San Antonio sheet: Austin, University of Texas, Bureau of Economic Geology, 8 p., 1 sheet.

Bullen, T.D., Krabbenhoft, David, and Kendall, Carol, 1996, Kinetic and mineralogic controls on the evolution of groundwater chemistry and ${ }^{87} \mathrm{Sr} /{ }^{86} \mathrm{Sr}$ in a sandy silicate aquifer, northern Wisconsin: Geochimica et Cosmochimica Acta, v. 60 , no. 10 , p. $1807-1821$.

Childress, C.J.O., Forman, W.T., Connor, B.F., and Maloney, T.J., 1999, New reporting procedures based on long-term method detection levels and some considerations for interpretations of water quality data provided by the U.S. Geological Survey National Water Quality Laboratory: U.S. Geological Survey Open-File Report 99-193, 19 p.

Clark, A.K., 2003, Geologic framework and hydrogeologic features of the Glen Rose Limestone, Camp Bullis Training Site, Bexar County, Texas: U.S. Geological Survey WaterResources Investigations Report 03-4081, 9 p., 1 pl. 
Clark, A.K., 2005, Geologic framework and hydrogeologic characteristics of the Glen Rose Limestone, Camp Stanley Storage Activity, Bexar County, Texas: U.S. Geological Survey Scientific Investigations Map 2831, scale 1:24,000.

Clark, Ian, and Fritz, Peter, 1997, Environmental isotopes in hydrogeology: Boca Raton, Fla., CRC Press, 328 p.

Clesceri, L.S., Greenberg, A.E., and Eaton, A.D., eds., 1998, Standard methods for the examination of water and wastewater (20th ed.): Washington, D.C., American Public Health Association [variously paged].

Craig, Harmon, 1961, Isotopic variations in meteoric waters: Science, v. 133, p. 1702-1703.

Cunningham, W.L., and Schalk, C.W., comps., 2011, Groundwater technical procedures of the U.S. Geological Survey: U.S. Geological Survey Techniques and Methods 1-A1, $151 \mathrm{p}$.

Donahue, D.J., Linick, T.W., and Jull, A.J.T., 1990, Isotoperatio and background corrections for accelerator mass spectrometry radiocarbon measurements: Radiocarbon, v. 32, book 2, p. 135-142.

Dunham, R.J., 1962, Classification of carbonate rocks according to depositional texture, in Classification of Carbonate Rocks Symposium: American Association of Petroleum Geologists Memoir 1, p. 108-121.

Edwards Aquifer Authority, 2012, Technical data: accessed June 27, 2012, at http://www.edwardsaquifer.org/display_ technical_m.php?pg=historical_data.

Ewing, T.E., 1996, Interesting places to view geology in the San Antonio area, in Ewing, T.E., ed., Rocks, landscape and man-Urban geology of the San Antonio area (2d ed.): Guidebook 96-2, South Texas Geological Society, 133 p.

Fairchild, I.J., Borsato, A., Tooth, A.F., Frisia, S., Hawkesworth, C.J., Huang, Y., McDermott, F., Spiro, B., 2000, Controls on trace element (Sr-Mg) compositions of carbonate cave waters - Implications for speleothem climatic records: Chemical Geology, v. 166, p. 255-269.

Ferrill, D.A., 2004, Structural framework of the Edwards Aquifer recharge zone in south-central Texas: GSA Bulletin, v. 116 , no. $3 / 4$, p. $407-418$.

Fishman, M.J., and Friedman, L.C., eds., 1989, Methods for determination of inorganic substances in water and fluvial sediments: U.S. Geological Survey Techniques of WaterResources Investigations, book 5, chap. A1, 545 p.

Fishman, M.J., ed., 1993, Methods of analysis by the U.S. Geological Survey National Water Quality LaboratoryDetermination of inorganic and organic constituents in water and fluvial sediments: U.S. Geological Survey OpenFile Report 93-125, p. 27-45.
Freeman, L.A., Carpenter, M.C., Rosenberry, D.O., Rousseau, J.P., Unger, Randy, and McLean, J.S., 2004, Use of submersible pressure transducers in water-resources investigations: U.S. Geological Survey Techniques of Water-Resources Investigations, book 8, chap. A3, 52 p., accessed July 23, 2012, at http://pubs.usgs.gov/twri/twri8a3/ pdf/twri8-a3.pdf.

Gagnon, A.R., and Jones, G.A., 1993, AMS-graphite target production methods at the Woods Hole Oceanographic Institution during 1986-1991: Radiocarbon, v. 35, book 2, p. 301-310.

Garbarino, J.R., 1999, Methods of analysis by the U.S. Geological Survey National Water Quality LaboratoryDetermination of dissolved arsenic, boron, lithium, selenium, strontium, thallium, and vanadium using inductively coupled plasma-mass spectrometry: U.S. Geological Survey Open-File Report 99-093, 31 p.

Garbarino, J.R., Kanagy, L.K., and Cree, M.E., 2006, Determination of elements in natural-water, biota, sediment and soil samples using collision/reaction cell inductively coupled plasma-mass spectrometry: U.S. Geological Survey Techniques and Methods, book 5, sec. B, chap. 1, 88 p.

Garza, S., 1962, Recharge, discharge, and changes in groundwater storage in the Edwards and associated limestones, San Antonio Area, Texas-A progress report of studies, 195559: Texas Water Development Board Bulletin 6201, p. 42.

George, W.O., 1952, Geology and ground-water resources of Comal County, Texas: U.S. Geological Survey WaterSupply Paper 1138, 126 p.

Hanson, J.A., and Small, T.A., 1994, Geologic framework and hydrogeologic characteristics of the Edwards aquifer outcrop, Comal County, Texas: U.S. Geological Survey Water-Resources Investigations 94-4117, 10 p., 1 pl.

Helsel, D.R., and Hirsch, R.M., 2002, Statistical methods in water resources: U.S. Geological Survey Techniques of Water-Resources Investigations, book 4, chap. A3, 510 p.

Hill, R.T., and Vaughn, T.W., 1898, Geology of the Edwards Plateau and Rio Grande Plain adjacent to Austin and San Antonio, Texas, with reference to the occurrences of underground waters, in Eighteenth Annual Report of the Director of the U. S. Geological Survey for the year 1896-1897, Part II, p. 193-321.

Kehew, Alan, 2001, Applied chemical hydrogeology: Upper Saddle River, N.J., Prentice-Hall, 368 p.

Koger, C.J., 1981, Depositional and diagenetic history of the Austin Chalk, central Texas, and its relationship to petroleum potential: Waco, Tex., Baylor University, master's thesis, $147 \mathrm{p}$. 
Larkin, T.J., and Bomar, G.W., 1983, Climatic atlas of Texas: Texas Department of Water Resources, Limited Printing Report LP-192, $151 \mathrm{p}$.

Lindgren, R.J., Dutton, A.R., Hovorka, S.D., Worthington, S.R.H., and Painter, Scott, 2004, Conceptualization and simulation of the Edwards aquifer, San Antonio region, Texas: U.S. Geological Survey Scientific Investigations Report 2004-5277, 143 p.

Livingston, Penn, 1947, Ground-water resources of Bexar County, Texas: Texas Board of Water Engineers, 234 p.

Maclay, R.W., 1995, Geology and hydrology of the Edwards aquifer in the San Antonio area, Texas: U.S. Geological Survey Water-Resources Investigations Report 95-4186, $69 \mathrm{p}$.

Maclay, R.W., and Land, L.F., 1988, Simulation of flow in the Edwards aquifer, San Antonio region, Texas, and refinement of storage and flow concepts: U.S. Geological Survey Water-Supply Paper 2336-A, 48 p.

Maclay, R.W., and Small, T.A., 1984, Carbonate geology and hydrology of the Edwards aquifer in the San Antonio area, Texas: U.S. Geological Survey Open-File Report 83-537, $72 \mathrm{p}$.

Mahler, B.J., 2008, Statistical analysis of major ion and trace element geochemistry of water, 1986-2006, at seven wells transecting the freshwater/saline-water interface of the Edwards aquifer, San Antonio, Texas: U.S. Geological Survey Scientific Investigations Report 2008-5224, 46 p.

Martinez, N., 1982, A regional subsurface study of the Austin Chalk, south Texas: Waco, Tex., Baylor University, master's thesis, $113 \mathrm{p}$.

McNichol, A.P., Gagnon, A.R., Jones, G.A., and Osborne, E.A., 1992, Illumination of a black box-Analysis of gas composition during graphite target preparation, in Long, A., and Kra, R.S., eds., Proceedings of the 14th International 14C Conference: Radiocarbon, v. 34, book 3, p. 321-329.

McNichol, A.P., Jones, G.A., Hutton, D.L. and Gagnon, A.R., 1994, The rapid preparation of seawater $\sum \mathrm{C} 02$ for radiocarbon analysis at the National Ocean Sciences AMS Facility: Radiocarbon, v. 36, book 2, p. 237-246.

Musgrove, M., and Banner, J.L., 2004, Controls on the spatial and temporal variability of vadose dripwater geochemistry-Edwards aquifer, central Texas: Geochimica et Cosmochimica Acta, v. 68, p. 1007-1020.

Musgrove, M., Fahlquist, L., Houston, N.A., Lindgren, R.J., and Ging, P.B., 2010, Geochemical evolution processes and water-quality observations based on results of the National Water-Quality Assessment Program in the San Antonio segment of the Edwards aquifer, 1996-2006: U.S. Geological Survey Scientific Investigations Report 2010-5129, 93 p.
Musgrove, M., Fahlquist, L., Stanton, G.P., Houston, N.A., and Lindgren, R.J., 2011, Hydrogeology, chemical characteristics, and water sources and pathways in the zone of contribution of a public-supply well in San Antonio, Texas: U.S. Geological Survey Scientific Investigations Report 2011-5146, 194 p.

National Oceanic and Atmospheric Administration, 2012, National Climatic Data Center GHCN daily for National Weather Service station 417945: National Oceanic and Atmospheric Administration, accessed June 7, 2012, at http://gis.ncdc.noaa.gov/map/cdo/?thm=themeDaily.

Navidi, W., 2008, Statistics for engineers and scientists (2d ed.): New York, McGraw-Hill, 901 p.

Oden, J.H., Brown, D.W., and Oden, T.D., 2011, Groundwater quality of the Gulf Coast aquifer system, Houston, Texas, 2010: U.S. Geological Survey Data Series 598, 64 p.

Pape, J.R., Banner, J.L., Mack, L.E., Musgrove, M., and Guilfoyle, Al., 2010, Controls on oxygen isotope variability in precipitation and cave drip waters, central Texas, USA: Journal of Hydrology, v. 385, p. 203-215.

Patton, C.J., and Kryskalla, J.R., 2011, Colorimetric determination of nitrate plus nitrite in water by enzymatic reduction, automated discrete analyzer methods: U.S. Geological Survey Techniques and Methods, book 5, chap. B8.

Pedraza, D.E., and Shah, S.D., 2010, Geodatabase design and characteristics of geologic information for a geodatabase of selected wells penetrating the Austin Group in central Bexar County, Texas, 2010: U.S. Geological Survey Data Series 522, $39 \mathrm{p}$.

Piper, A.M., 1944, A graphic procedure in the geochemical interpretation of water analyses: Transactions, American Geophysical Union, v. 25, p. 914-923.

Révész, Kinga, and Coplen, T.B., 2008a, Determination of the $\delta\left({ }^{18} 0 /{ }^{16} 0\right)$ of water-RSIL lab code 489 , chap. C2 of Révész, Kinga, and Coplen, T.B., eds., Methods of the Reston Stable Isotope Laboratory: U.S. Geological Survey Techniques and Methods, book 10, sec. C, chap. 2, 28 p.

Révész, Kinga, and Coplen, T.B., 2008b, Determination of the $\delta(2 \mathrm{H} / 1 \mathrm{H})$ of water-RSIL lab code 1574 , chap. C1 of Révész, Kinga, and Coplen, T.B., eds., Methods of the Reston Stable Isotope Laboratory: U.S. Geological Survey Techniques and Methods, book 10, sec. C, chap. 1, 27 p.

Rybczyk, M.L., 1992, San Antonio uncovered: Wordware Publishing Inc., Plano, Tex., 290 p.

Schneider, R.J., Jones, G.A., McNichol, A.P., von Reden, K.F., Elder, K.A., Huang, K., and Kessel, E.D., 1994, Methods for data screening, flagging, and error analysis at the National Ocean Sciences AMS Facility: Nuclear Instruments and Methods in Physics Research, book 92, p. 172-175. 
Sellards, E.H., Adkins, W.S., and Plummer, F.B., 1923, The geology of Texas-Volume I, stratigraphy: Austin, University of Texas, Bureau of Economic Geology Bulletin $3232,1,007 \mathrm{p}$.

Small, T.A., 1986, Hydrogeologic sections of the Edwards aquifer and its confining units in the San Antonio area, Texas: U.S. Geological Survey Water-Resources Investigations Report 85-4259, $52 \mathrm{p}$.

Sharp, J.M., Jr., and Banner, J.L., 1997, The Edwards aquifer-A resource in conflict: Geological Society of America Today, v. 7, p. 1-9.

Stein, W.G., and Ozuna, G.B., 1995, Geologic framework and hydrogeologic characteristics of the Edwards aquifer recharge zone, Bexar County, Texas: U.S. Geological Survey Water-Resources Investigations Report 95-4030, $8 \mathrm{p}$.

Texas Commission on Environmental Quality, 2012, Proclamation by the Governor of the State of Texas: accessed June 27, 2012, at http://www.tceq.texas.gov/assets/ public/response/drought/20120518disaster-proclamationrenewed.pdf.

Texas State Historical Association, 2012, Alamo Cement Company: accessed July 12, 2012, at http://www.tshaonline. org/handbook/online/articles/dlauy.

U.S. Census Bureau, 2010, Texas State and county quick facts: accessed May 1, 2012, at http://quickfacts.census.gov/qfd/ states/48000.html.
U.S. Geological Survey, 2006, Collection of water samples (ver. 2.0): U.S. Geological Survey Techniques of Water-Resources Investigations, book 9, chap. A4, accessed September 19, 2012, at http://pubs.water.usgs.gov/ twri9A4/.

U.S. Geological Survey, 2012, USGS water data for Texas: National Water Information System, accessed April 4, 2012, at http://waterdata.usgs.gov/tx/nwis/nwis.

U.S. Geological Survey, variously dated, National field manual for the collection of water-quality data: U.S. Geological Survey Techniques of Water-Resources Investigations, book 9 , chaps. A1-A9, accessed September 17, 2012, at http://water.usgs.gov/owq/ FieldManual/index.html.

Veni, G., 1988, The caves of Bexar County (2d ed.): Austin, Tex., Texas Memorial Museum Speleological Monographs $2,300 \mathrm{p}$.

Vogel, J.S., Nelson, D.E., and Southon, J.R., 1987, 14C background levels in an accelerator mass spectrometry system: Radiocarbon, v. 29, book 3, p. 323-333.

Wilde, F.D., ed., variously dated, National field manual for the collection of water-quality data-Field measurements: U.S. Geological Survey Techniques of Water-Resources Investigations, book 9, chap. A6, sections 6.0-6.8, accessed January 27, 2012, at http://pubs.water.usgs.gov/ twri9A6/.
Publishing support provided by

Lafayette Publishing Service Center
Information regarding water resources in Texas is available at

http://tx.usgs.gov/ 



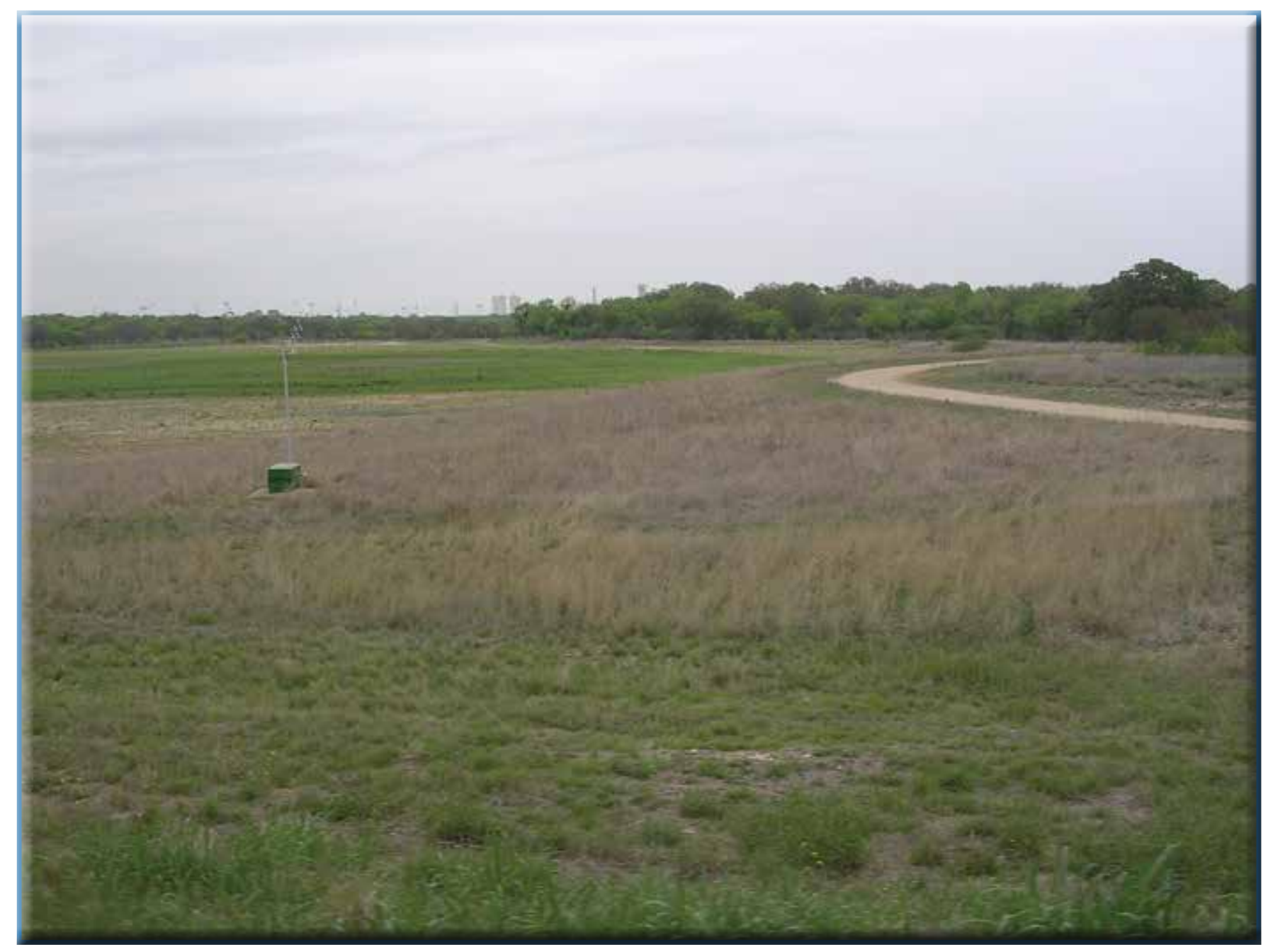

